\title{
$\mathrm{AHRS}$ 를 이용한 무선 선체 운동 측정 시스템에 관한 연구 \\ 김대해*•+ 이상민 · 공길영** \\ * 한국해양대학교 대학원, † 군산대학교 해양생산학과 교수, ** 한국해양대학교 항해학부 교수
}

\section{A Study on the Wireless Ship Motion Measurement System Using AHRS}

\author{
Dae-Hae Kim* • + Sang-Min Lee • Gil-Young Kong** \\ * Graduate School of Korea Maritime \& Ocean University, Busan 606-791, Korea \\ + Dept. of Marine Science and Production, Kunsan National University, Kunsan 573-701, Korea \\ * Dept. of Navigation Science, Korea Maritime \& Ocean University, Busan 606-791, Korea
}

요 약 : IMU(Inertial Measurement Unit)는 선박, 잠수함, 항공기 및 군용장비 응용분야에서 적용되어 자세 측정 영역에 주로 사용되고 있지 만, 이런 $\mathrm{IMU}$ 는 고가의 장비이기 때문에 특수 분야에서만 한정적으로 이용되어 왔다. 그러나 MEMS AHRS(MEMS : Micro Electro Mechanical System, AHRS : Attitude and Heading Reference System)의 현 기술 상황은 지능형 MEMS AHRS가 채택된 응용분야에서 가격 이 높은 IMU를 대체 할 수 있는 수준에 이르고 있다. 본 논문에서는 자이로 센서, 가속도 센서, 지자기 센서를 사용한 AHRS를 이용하여 선박 의 주요 운동 요소인 횡동요, 종동요, 선수동요 값을 측정할 수 있는 무선 선체 운동 측정 시스템을 개발하였다. 또한 AHRS 센서가 발생시키 는 오차인 순간 가속도, 지자기의 영향 및 진동에 대응하기 위하여 칼만 필터링 기능이 탑재된 센서를 적용함으로서 최적의 성능을 실현하고자 하였다. 본 연구에서 구현한 AHRS 센서를 이용한 무선 선체 운동 측정 시스템을 이용하여 실선 실험을 실행하였으며, 선박의 제한적인 설치 상황에서도 편리하게 적용할 수 있을 것으로 보여진다. 향후 이 시스템이 선박에서 INS(Integrated Navigation System) 및 VDR(Voyage Data Recorder)과 같은 선박 장비와 호환되어 활용될 경우 항해 안전과 해양사고 분석에 유용하게 사용될 수 있을 것으로 판단된다.

핵심용어 : 관성측정장치, 초소형 전기기계장치, 자세방위결정시스템, 선체 운동, 항해 안전

Abstract : The IMU(Inertial Measurement Unit) which is the expensive equipment has been used as a special limited area, usually in measurement of posture of applying to the areas of ship, submarine, aircraft and military equipment application. However, in the current situation, MEMS AHRS technology can replace the high-priced IMU in MEMS AHRS selected application field. In this paper, wireless hull motion measurement system was suggested for measuring key elements of ship's movement such as rolling, pitching and yawing using gyro, acceleration and magnetic sensors of AHRS. In order to reduce the error such as instantaneous acceleration, effects and vibration of geomagnetic, we have adopted the sensors equipped with Kalman filtering. The Wireless hull motion measurement system using AHRS sensors was tested in actual ship and it could easily be applied in limited installation circumstances of the ship. In the future, this system can be useful in the navigation safety and marine accident analysis by using with ship equipment such as INS or VDR in the maritime.

Key words : IMU, MEMS, AHRS, ship motion, navigation safety

\section{1. 서 론}

선박의 항해 및 계류 안전성 평가에 기초가 되는 선체 운동 요소와 선박 가속도 값을 계측하기 위해서 가속도계, 방위 센서, 경사계, 초음파 변위계 등 여러 특정 센서를 이용한 다 방면에서 효과적으로 선체 운동 계측 시스템을 개발하려는 노력이 있어 왔다(Kim et al., 2005). 선박에 가속도계 등을 설치하여 운동 운항환경을 모니터링 할 수 있는 시스템 개발
에 관한 연구가 수행되었으나(Yoon et al., 2008), 파워선 통 신의 제약 등으로 인하여 원하는 위치에 적절히 설치할 수 없는 문제점을 내포하고 있다. 다양한 환경적 변수가 많은 해상에서 선체 운동을 계측하는 것은 많은 기술적 어려움과 고가의 특수 센서로 주로 구현됨에 따라 일반 상선에서는 채 택되지 못했다. 2000년대에 들어서 MEMS(Micro Electro Mechanical System)의 발달로 저가이면서 소형의 관성 센서 들이 많이 개발되고, 센서 데이터를 처리할 마이크로 프로세

* 종신회원, sun2hae@kmou.ac.kr 051)410-4765

† Corresponding author : 종신회원, smlee@kunsan.ac.kr 063)469-1814

** 종신회원, kong@kmou.ac.kr 051)410-4761

(주) 이 논문은 “AHRS 센서 기반의 무선 선체운동 모니터링 알고리즘의 개발”이란 제목으로 2013년도 한국해양과학기술협의회 공동학 술대회에서 발표된 논문(제주국제컨벤션센터, 2013.5.23 - 25, pp.187)을 수정 보완한 논문임. 
서의 처리 속도도 향상되어 고성능 제품으로 시장에 자리를 잡아가고 있는 추세이다(Priyanka et al., 2010).

관성측정장치(IMU, Inertial Measurement Unit)는 가속도 계, 각속도계 등의 관성 센서를 이용하여 움직이는 물체의 위치, 자세, 속도, 가속도 및 각속도의 정보를 취득하는데 효 과적으로 이용할 수 있으며, 최근에는 가격이 저렴한 MEMS $\mathrm{AHRS}$ 센서가 여기에 접목되어 일반 상용화 되어 가고 있다 (Zhu et al., 2007).

이런 저가의 MEMS AHRS를 이용한 소형 항법 시스템이 사용되는 대표적인 예로 무인항공기를 들 수 있으며, 저가의 관성항법 시스템의 경우 시간이 지남에 따라 정확도가 떨어 지는 단점을 해결하기 위해 $\mathrm{MEMS}$ 센서 기술을 이용한 $\mathrm{GPS} / \mathrm{AHRS}$ 소형 항법시스템 설계에 관한 연구도 활발히 진 행중이다(Kwon et al., 2005).

기존의 내항성능 평가 요소는 한계발생확률이 각기 다르게 제안되어져 있기 때문에 선박 전체의 내항성능을 평가하기 위해서는 모든 요소들의 계측을 필요로 한다. 이러한 평가 방법상의 문제점을 개선하고 평가 요소 계측상의 어려움을 해결할 수 있는 방법으로, 임의의 대표 요소 한가지에 의한 선박 전체의 항해안전성 평가에 대한 연구가 진행중이다. 이 에 본 연구는 실제 해상에서 선체 운동 요소를 계측하고, 계 측된 데이터의 처리 및 해석을 통하여 선박의 종합적인 항해 안전성을 평가할 수 있는 시스템 개발의 기초 연구로서 수행 되었다. 본 연구에서는 $\mathrm{AHRS}$ 센서 자체의 특성 오차와 장시 간 사용으로 인한 누적 오차를 보정하기 위해 칼만 필터링 기능이 탑재된 센서를 선정하여 선체 운동 계측 시스템에 적 용하였다. 그리고, 제한된 환경인 선박에서 선체 운동 계측을 효과적으로 계측하기 위하여 무선 시스템을 접목시킨 무선 선체 운동 계측 시스템을 개발하였으며, 본 시스템을 이용하 여 실선에서의 실험을 수행하였다.

\section{2. 무선 선체 운동 계측 시스템 설계}

무선 선체 운동 계측 시스템은 세 부분으로 구성하여 설계 하였다. AHRS 센서를 사용하여 항해중인 선박의 횡동요, 종 동요, 선수동요 데이터를 측정하는 선체 운동 계측 부분, 측 정된 데이터를 무선 네트워크를 통하여 전송하는 무선 센서 네트워크 부분과 전송된 데이터를 수신하여 정보 처리하는 데이터 수집 처리 부분이다.

\section{1 선체 운동 계측부}

본 연구에서 선체 운동을 실시간 계측하기 위해 사용된 관 성측정장치(IMU)의 자세측정시스템(AHRS) 센서는 3축 MEMS 가속도(Accelerometer), 자이로스코프(Gyroscope), 지자기(Magnetometer) 센서로 구성되어 있으며, 이는 3축에 직각으로 배치되어 총 9축이 측정되므로 각 센서로부터 선체 운동을 6 자유도(DOF: Degree of Freedom) 요소를 계측하
여 결과 값을 얻을 수 있다. 선체운동 계측부에 적용한 센서 는 시중에서 판매하는 저가의 상용 제품인 $32 \mathrm{Bit}$ MCU(Micro Controller Unit)를 탑재한 디지털 타입의 $\mathrm{AHRS}$ 모듈 센서와 정밀도가 높은 $6 \mathrm{DOF}$ 및 범용 $3 \mathrm{DOF}$ 계측용 MEMS AHRS 센서를 사용하였다. Fig. 1은 구축된 IMU의 구조도를 나타내고 있다(JK electronics, 2012).

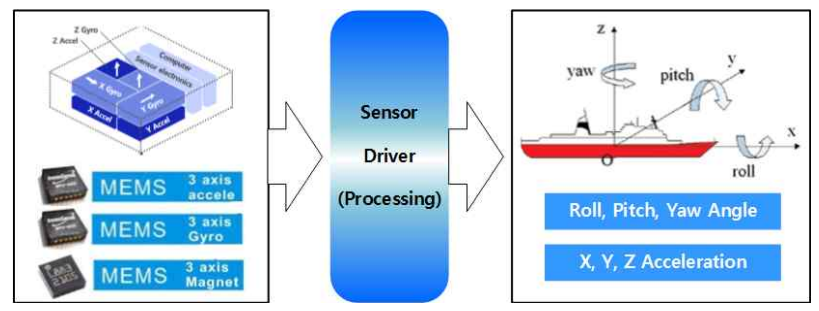

Fig. 1 Application diagram of IMU

Fig. 2는 MEMS AHRS 센서의 내부 및 외부 데이터 처리 과정을 보여주는 도표이다(Ruva tech, 2011). Table 1은 선체 운동 계측부에 사용된 IMU의 MEMS AHRS 센서 사양을 나타내었다.

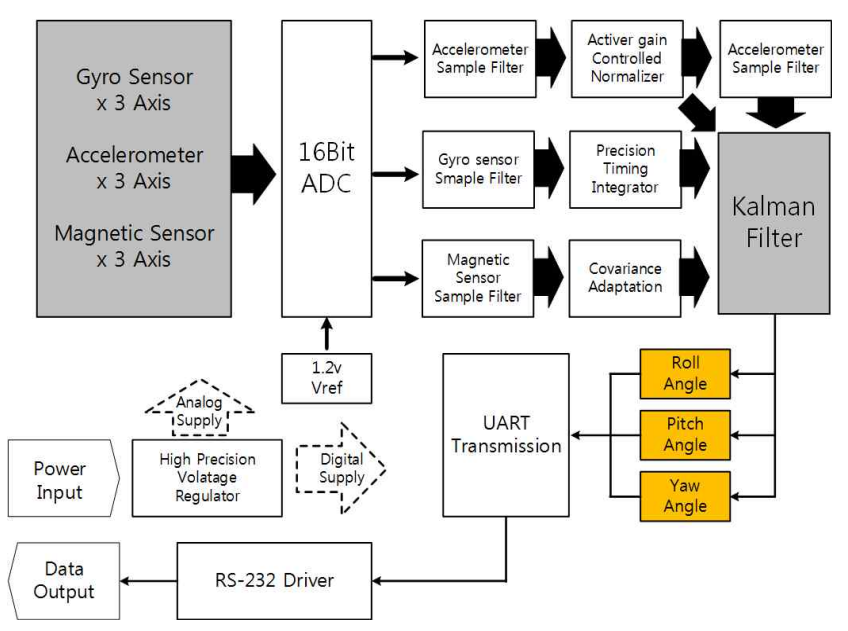

Fig. 2 Structure block diagram of MEMS AHRS

Table 1 Specification of MEMS AHRS Sensors

\begin{tabular}{l|l|l|l}
\hline $\begin{array}{c}\text { Sensor } \\
\text { Spec. }\end{array}$ & $\begin{array}{c}\text { Gyroscope } \\
(\text { MPU6050) }\end{array}$ & $\begin{array}{c}\text { Accelerometer } \\
\text { (MPU6050) }\end{array}$ & $\begin{array}{c}\text { Magnetic } \\
(\text { HMC5883L) }\end{array}$ \\
\hline Interface & $\mathrm{I}^{2} \mathrm{C}$ interface & $\mathrm{I}^{2} \mathrm{C}$ interface & $\mathrm{I}^{2} \mathrm{C}$ interface \\
\hline Startup & $100 \mathrm{~ms}$ & $100 \mathrm{~ms}$ & $50 \mathrm{~ms}$ \\
\hline Range & $\begin{array}{l} \pm 2000 \sim \\
\pm 250 \mathrm{~d} / \mathrm{s}\end{array}$ & $\pm 16 \sim \pm 2 G$ & $\begin{array}{l} \pm 8 \sim \pm 1 \\
\text { Gaussian }\end{array}$ \\
\hline $\begin{array}{l}\text { Resolution } \\
\text { (Sensitivity } \\
\text { Scale Factor) }\end{array}$ & $\begin{array}{l}16.4 \mathrm{LSB} / \\
(\text { degree/s) }\end{array}$ & $\begin{array}{l}2048 \mathrm{LSB} / \\
(\text { degree/s) }\end{array}$ & 4.35 milli-gauss \\
\hline Update Rate & $4^{\sim 8000 ~ h z}$ & $4^{\sim} 1000 \mathrm{hz}$ & $0.75 \sim 75 \mathrm{~h} z$ \\
\hline
\end{tabular}

\section{2 무선 센서 네트워크부}

무선 센서 네트워크(WSN, Wireless Sensor Network)는 
공간 및 위치에 제약 없이 다양한 공간에 설치되어 주위 환 경 정보를 수집한 뒤 센서 노드들 간의 독립적인 무선 네트 워크를 통해 목적지로 전송할 수 있는 기술이다. 특히 선박 의 제한된 환경에서 이러한 장점을 지닌 $\mathrm{WSN}$ 을 적용하여 선박 내 외부의 근거리 통신망의 활용을 통한 선박 환경에 최적화된 선체 운동 계측 시스템의 무선 네트워크 망을 구축 하였다. Fig. 3은 일반적으로 직렬 통신 처리를 하는 장비의 무선 센서 네트워크 구성도를 나타내며, UART(Universal Asynch- ronous Receiver \& Transmitter)를 사용하는 장비 와 $\mathrm{Wi}-\mathrm{Fi}$ 망을 공유하기 위한 $\mathrm{UDP}(\mathrm{User}$ Datagram Protocol) 기반의 네트워크 모델이다.

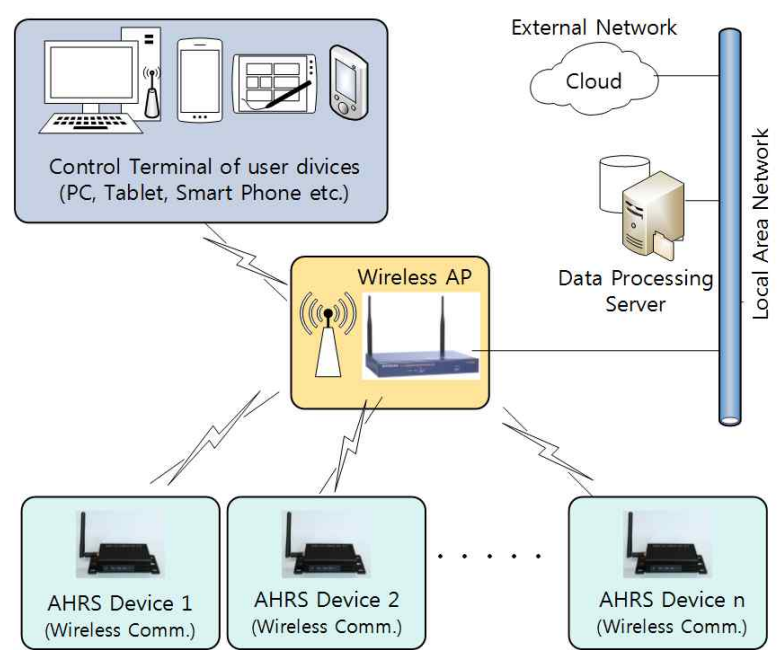

Fig. 3 Wireless sensor networking for serial device

무선 센서 네트워크부는 전형적인 무선 통신 방식과 동일 하게 데이터를 전송하는 송신부와 데이터를 수신하는 수신부 로 구성되어 있다. 송신부에서는 MEMS AHRS 센서에 의해 획득한 데이터를 WIFI-RS232C 변환모듈을 사용하여 직렬 통신 방식인 $\mathrm{RS}-232 \mathrm{C}$ 를 지원하는 주변기기를 손쉽게 무선 랜 $(\mathrm{Wi}-\mathrm{Fi})$ 을 이용하는 $\mathrm{WSN}$ 에 접속하여 통신한다. 수신부인 $\mathrm{PC}$ 측에서도 $\mathrm{WSN}$ 에 접속하여 $\mathrm{IMU}$ 또는 $\mathrm{AHRS}$ 센서부에 직접 연결하여 계측 데이터를 수신 받는다. 본 연구에 의해 구현된 무선 센서 네트워크를 구성하는데 사용된 부품들의 사양을 Table 2에 나타내었고, Fig. 4는 계측센서의 무선 통 신 장치 구성을 보여준다.

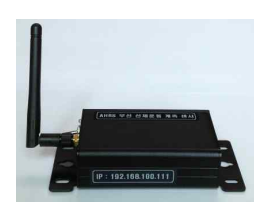

(a)

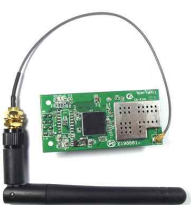

(b)

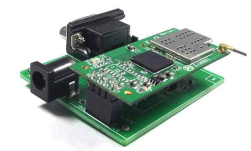

(c)
Fig. 4 Wireless sensor communication device (a) AHRS main unit body, (b) WiFi-RS232C transmitter, (c) RS232C-TTL convertor
Table 2 Specification of device used for wireless sensor communication

\begin{tabular}{l|l|l}
\hline \multicolumn{2}{|c|}{ Items } & \multicolumn{1}{c}{ Parameters } \\
\hline \multirow{4}{*}{ Wi-Fi } & Wireless standard & IEEE $802.11 \mathrm{~b} / \mathrm{g}$ \\
\cline { 2 - 3 } & Frequency range & $2.412 \sim 2.484 \mathrm{GHz}$ \\
\cline { 2 - 3 } & Receiver/Transfer & $\begin{array}{l}802.11 \mathrm{~b} / \mathrm{g} \\
(11 \mathrm{Mbps} / 54 \mathrm{Mbps})\end{array}$ \\
\hline \multirow{4}{*}{$\mathrm{H} / \mathrm{W}$} & Serial type & $\mathrm{UART}$ \\
\cline { 2 - 3 } & Serial rate & $1200 \sim 115200 \mathrm{bps}$ \\
\cline { 2 - 3 } & Operating voltage & $3.3 \pm 0.3 \mathrm{~V}$ \\
\hline \multirow{2}{*}{ S/W } & Network protocol & $\mathrm{TCP} / \mathrm{UDP} / \mathrm{ARP} / \mathrm{ICM} / \mathrm{DHCP} / \mathrm{HTTP}$ \\
\hline
\end{tabular}

\section{3 데이터 수집 처리부}

선체 6자유도 운동의 3요소(횡동요, 종동요, 선수동요)와 가속도를 계측하기 위한 $\mathrm{AHRS}$ 센서의 데이터를 획득하고 분석하기 위하여 센서 제작 업체에서 개발 툴로 제공하는 NT-ARS와 Uni-Matrix의 두 가지 프로그램을 사용하여 $\mathrm{AHRS}$ 센서 계측 데이터 모니터링 및 수집 작업을 하였다. 이 S/W는 AHRS 센서 데이터 수집 및 제어가 가능한 프로 그램으로서 센서별 통신 포트 설정, 센서 보정, 주파수 설정 등의 기능이 있고, 센서 계측 값의 텍스트 데이터, 그래프 표 시, $2 \mathrm{D}$ 그래프와 $3 \mathrm{D}$ 그래픽 구현이 되어 사용상 편리성과 결 과 데이터를 다양하게 가공할 수 있다.

Fig. 5와 6은 MEMS AHRS 센서를 이용한 데이터 획득 프로그램 $(\mathrm{DAQ})$ 으로 실시간 측정된 계측 데이터를 표시하고 저장하고 있는 모습을 보여주고 있다.

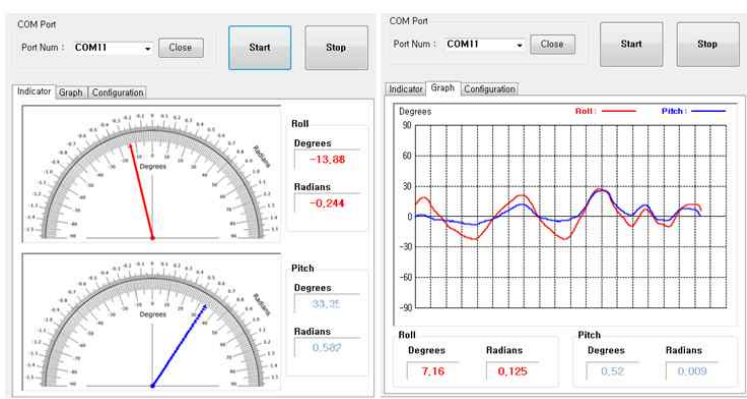

Fig. 5 Data aquisition program using NT-ARS

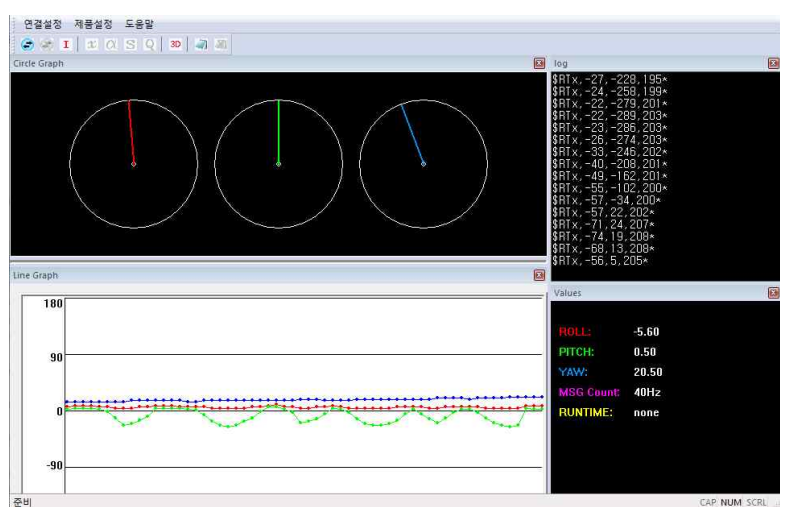

Fig. 6 Data aquisition program using Uni-Matrix 


\section{3. 실선 실험}

\section{1 실험 대상 선박의 제원 및 계측 방법}

해상에서의 실선 실험을 위하여 한국해양대학교 실습선 한 바다호를 실험 모델로 선정하였다. Table 3과 Fig. 7은 실험 선박의 주요 제원과 일반 배치도를 보여주고 있다.

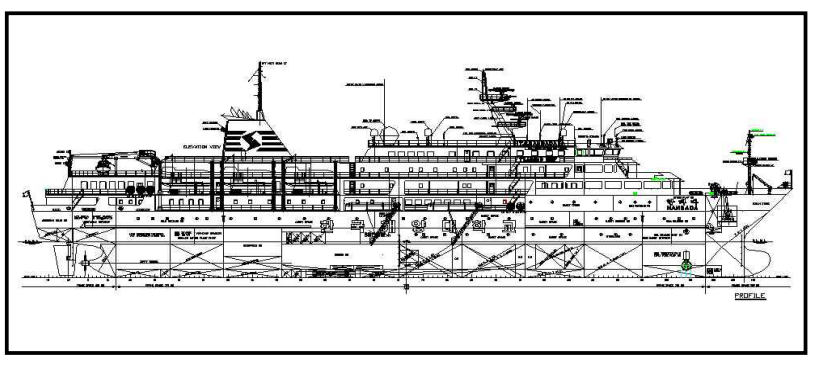

Fig. 7 General arrangement of T.S. HANBADA

Table 3 General particulars of training ship

\begin{tabular}{l|c}
\hline \multicolumn{1}{c|}{ Items } & Dimensions \\
\hline \hline LOA / LBP & $117.2 \mathrm{~m} / 104.0 \mathrm{~m}$ \\
\hline Breadth & $17.8 \mathrm{~m}$ \\
\hline Displacement & $6,434 \mathrm{ton}$ \\
\hline Max. Speed / Service Speed & $19.0 \mathrm{kts} / 17.5 \mathrm{kts}$ \\
\hline
\end{tabular}

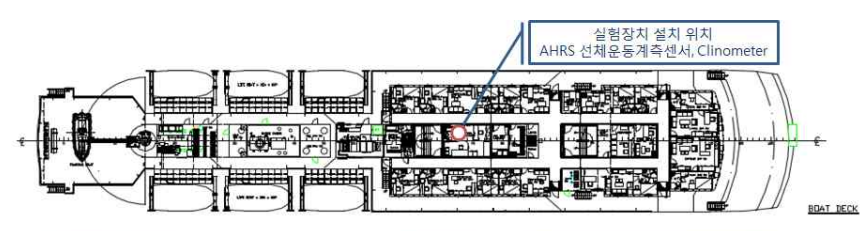

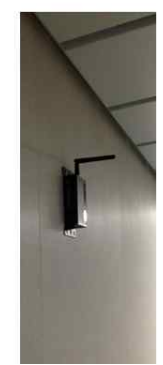

(a)

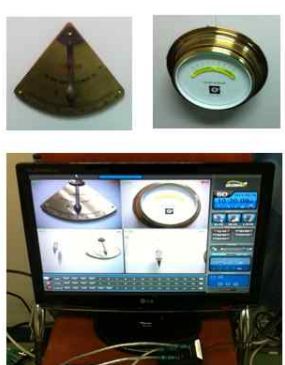

(b)

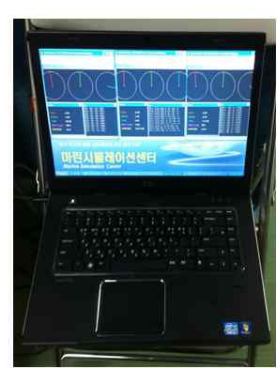

(c)
Fig. 8 Arrangement of AHRS sensors at T.S. HANBADA (a) installation of AHRS, (b) inclinometer \& DVR and (c) measurement $\mathrm{S} / \mathrm{W}$

파랑 중 선박의 횡동요, 종동요, 선수동요는 동시에 변화하 기 때문에 정확한 선체 운동 계측을 위해서는 IMU를 선박의 무게 중심점에 설치하여 데이터를 획득하는 것이 좋으나, 현 실적으로 선박의 구조 요건상 무게 중심점에 $\mathrm{IMU}$ 를 설치하 기가 어렵고 무게 중심 또한 선박 화물의 적양하 상황이나 본선 컨디션에 따라 변화하기 때문에 정확한 위치에 설치하 는 것은 불가능하다. 본 연구에 적용한 계측 장비는 크기가 작고 무선으로 데이터 처리가 가능하여, 선교 또는 기타 선 내 특정 장소에 쉽게 설치 할 수 있으므로 실선 실험에서는
실습선 한바다호의 무게중심 근처 상부 부근에 위치한 지점 의 장소를 선정하여 실험하였다. 실험 계측치의 보정은 설치 장소와 선체 운동의 중심점과의 좌표 값을 이용하여 선체운 동 계측 값을 분석하였다. Fig. 8은 AHRS 무선 선체 운동 모니터링 장비와 실선의 선체 운동을 계측하는 경도계를 설 치한 모습이다.

\section{2 실선 계측 자료 분석}

\section{1) 실선 실험 조건}

실선 실험은 한바다호의 2013년도 제1차 연안항해 기간 중 인 3월 18 일에서 3 월 22 일 사이에 2 회에 걸쳐 선상에서 실시 하였다. Fig. 9 및 Table 4에서와 같이 실험 대상 선박이 부 산-제주 항해구간에서 1 차 실험은 남서 방향으로 항해하면 서 계측되었으며, 2 차 실험은 반대로 북동 방향으로 항해하 면서 조사되었다.

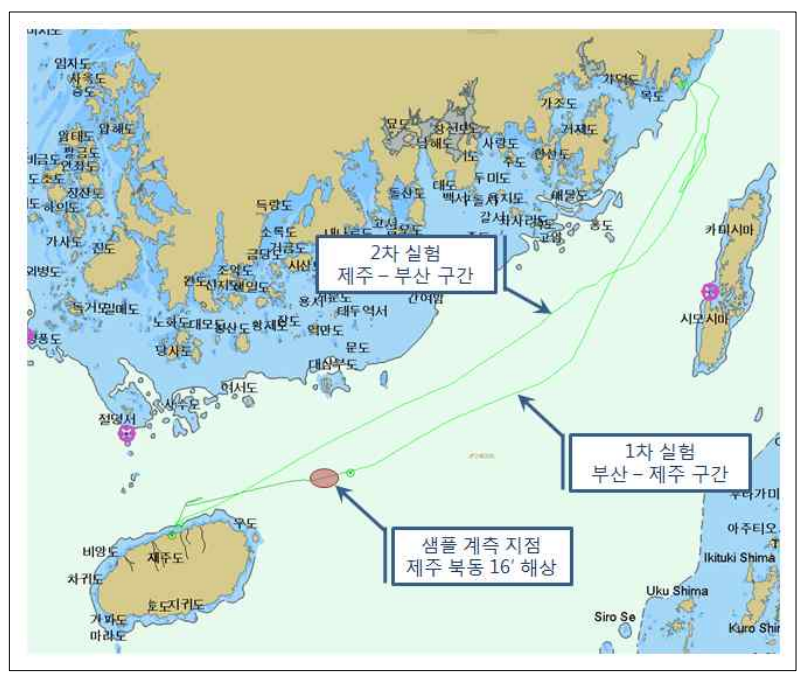

Fig. 9 Track of actual ship test

Table 4 Condition of actual ship test

\begin{tabular}{c|c|c}
\hline Items & Test 1 & Test 2 \\
\hline Date & 2013.03.18. $\sim 3.19$ & 2013.03.21. 3.22 \\
\hline Wind & SW, $20 \sim 28 \mathrm{kts}$ & NW, $5 \sim 10 \mathrm{kts}$ \\
\hline Wave & SW, $2.0 \mathrm{~m}$ & NW, $0.5 \mathrm{~m}$ \\
\hline Current & SE, $0.5 \mathrm{kts}$ & NE, $0.2 \mathrm{kts}$ \\
\hline Distance & $175 \mathrm{~nm}$ & $195 \mathrm{~nm}$ \\
\hline
\end{tabular}

1 차 실험은 실험 개시 후 종료시까지 총 13.5 시간이 소요 되었고 그 거리는 175 마일 항해하였으며, 2차 실험은 총 14.5 시간이 소요되었고 195 마일 항진하였다. 실험 당시의 기상 조건으로 풍향 풍속계 관측에 의한 평균 풍속은 1 차에서 20 노트 이상, 2 차에서 10 노트 이하이었으며, 당직 항해사들에 게 의해 목측된 해상 상태는 1차에서 파고 2.0 미터 이하, 2차에 서는 0.5 미터 이하로 관측되었다. 1 차 실험에서의 날씨는 해 상 및 기상 상태가 풍랑이 이는 상황이었고, 2차 실험은 비교 적 평온한 편이었다. 또한, 조류에 의한 외력의 경우 대지속 
력과 대수속력을 비교하여 측정하였으며, 1 차에서는 선박의 진행방향에 대하여 역방향(역조) 그리고 2 차에서는 순방향 (순조)으로 작용하였다.

\section{2) 실선의 선체 운동 계측}

실선에서의 운항중 해상 실험은 먼저 출항전 접안한 부두 에서 $\mathrm{AHRS}$ 센서의 자세 결정과 선수각의 오차를 보정하기 위해서 고정판에 각 센서를 고정하고 횡동요와 종동요 값의 0점 보정 작업과 선수방향(heading)을 선박의 자이로 컴파스 값과 일치시켜 초기 설정을 하였고, 전용 데이터 수집 $\mathrm{S} / \mathrm{W}$ 를 사용하여 출항 후 30 분 간격으로 횡동요, 종동요, 선수동 요의 데이터를 취득 및 저장하였다.

$\mathrm{AHRS}$ 센서 계측값의 검증을 위한 실선에서의 실제 측정 은 선체 중앙부에 위치한 지점에서 JIN HANG Marine Equipment사와 LILLEY \& GILLIE사에서 제작된 눈금간격 이 $1^{\circ}$ 인 아날로그 선박용 경사계(clinometer)를 설치하여 횡 동요와 종동요를 실측하였고, 경사계의 움직임을 $\mathrm{CCTV}$ 로 촬영하여 영상을 시간 정보를 포함하고 있는 DVR(Digital Video Recorder) 시스템에 기록하여 실험 후 데이터 분석시 에 시간대별 검색이 가능하도록 하였다. 실제 선수동요 계측 은 ECDIS 시스템에서 NMEA0183 표준 포맷으로 기록된 GYRO (TokyoKeiki TG-8000 Model) heading 값(진방향)을 10 times/sec heading update rate로 추출하여 측정하였다. AHRS 센서에 의한 선수동요를 측정하기 위한 방법으로는 지자기 센서로 감지되는 각도 값을 초기 설정 때 Gyroscope 에서 받은 진방위 값을 기준으로 보정하여 항해시에는 좌우 측 각도 변동량을 측정하였다.

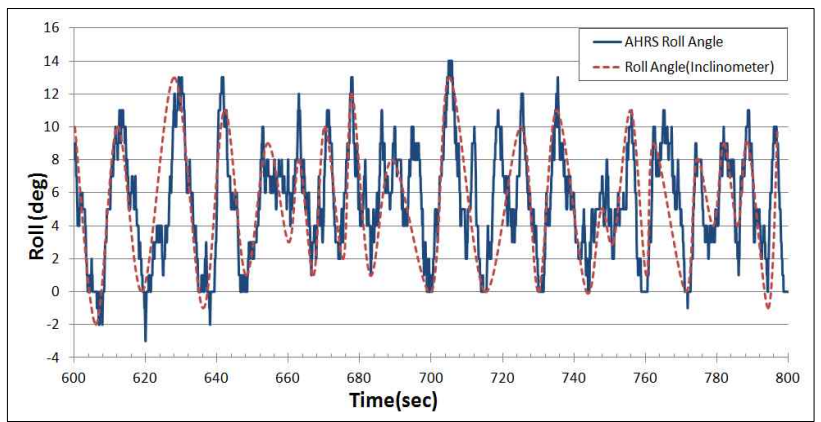

Fig. 10 AHRS outputs and actual values of roll angle

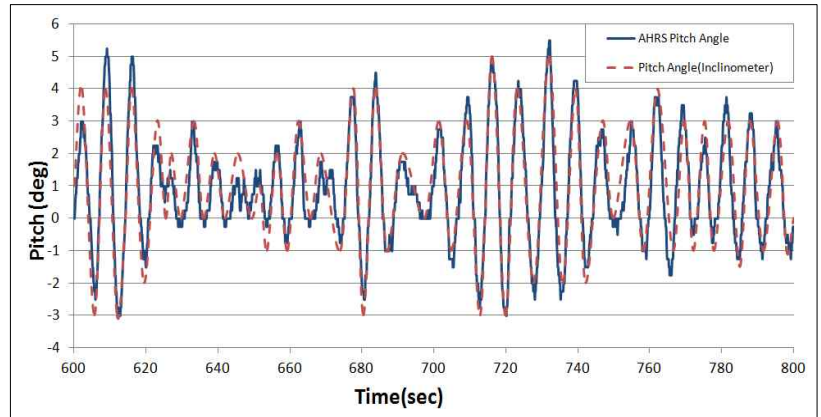

Fig. 11 AHRS outputs and actual values of pitch angle

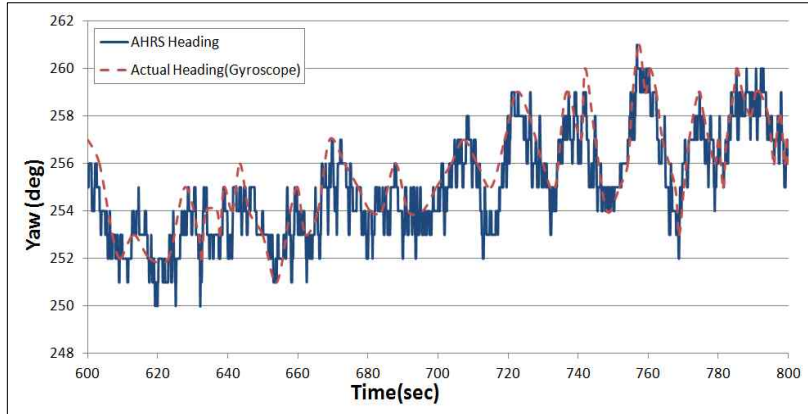

Fig. 12 AHRS outputs and actual values of yaw angle

3) 계측 자료의 분석

Figs. 10, 11, 12는 1차 실험 구간인 부산-제주 항해 구간 중에서 횡동요 및 종동요가 심했던 2013년 3월 19일 04시 10 분(한국표준시)부터 약 3 분간(600 800초 구간) $33^{\circ} 41.5^{\prime} \mathrm{N}$, $127^{\circ} 04.4^{\prime} \mathrm{E}$ 의 지점(Fig. 9에 샘플 계측 지점 표시)에서 횡 동요, 종동요, 선수동요의 계측 결과를 AHRS 센서에 의한 결 과와 실제 측정치를 함께 도시하였다. 본 연구는 선박의 내항 성능 평가를 위한 선체 운동 요소의 유의 진폭치 계산에 필 요한 표준편차 값을 구하기 위하여 $\mathrm{AHRS}$ 를 이용하여 무선 으로 횡동요와 같은 선체 운동 요소를 계측하고 해석을 수행 하고자 한 연구이다. 따라서 선체 운동이 다른 항해 구간보다 비교적 크게 발생한 1차 실험 구간에서의 샘플링 구간을 선 정하였으며, $\mathrm{AHRS}$ 에 의한 계측 값과 경사계 등에 의한 실측 값을 상호 비교하고 있다. 실선 실험 선박인 한바다호의 횡동 요 주기는 계산값이 10.2초, 실측 평균 값이 8.6초로 선체가 낮은 주기로 움직이므로 각 AHRS 센서마다 sampling rate를 $10 \mathrm{~Hz}$ 로 하여 센서 계측 값을 취득하였다. 샘플링 구간에서의 계측 데이터의 $\mathrm{AHRS}$ 센서 계측치 값은 횡동요각 $-3^{\circ}$ $14^{\circ}$, 종동요각 $-3^{\circ} \sim 5.5^{\circ}$, 선수동요각 $250^{\circ} \sim 261^{\circ}$ 을 얻을 수 있었고, 실제 측정치 값은 횡동요각 $-2^{\circ} \sim 13^{\circ}$, 종동요 각 $-3^{\circ} \sim 5^{\circ}$, 선수동요각 $251^{\circ} \sim 261^{\circ}$ 의 범위에 있었다. 센 서 계측치와 실측치의 최대 및 최소 진폭치가유사하다는 것 을 알 수 있다.

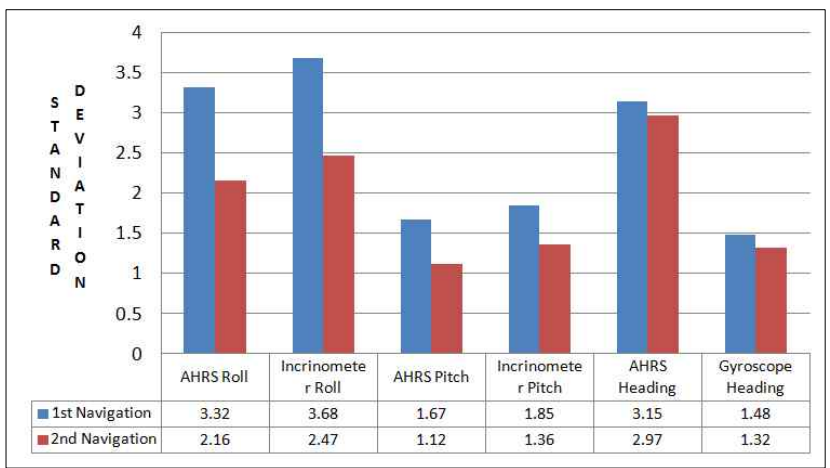

Fig. 13 Standard deviation of AHRS and actual measurement 
Fig. 13 은 1,2 차 실험 전 구간에서의 AHRS 센서 계측치와 실측치의 표준편차를 비교한 표이다. 표준편차를 알 수 있으 면 특정 항해 구간에서의 횡동요와 같은 선체 동요의 $1 / 3$ 유 의 진폭치를 쉽게 파악할 수 있으며, 이러한 선체 동요의 유 의 진폭치를 이용하여 선박의 항해안전성을 평가할 수 있게 된다. AHRS로 계측된 데이터의 표준편차 값을 토대로 한 종 동요 및 횡동요의 유의 진폭치와 실측된 운동 진폭치와는 유 사한 값을 나타내고 있다. 즉 1차 항해 구간에서의 AHRS에 의한 횡동요의 유의 진폭치와 실측에 의한 운동 진폭치의 차 이는 0.9 도, 종동요 진폭치의 차이는 0.7 도 차이가 발생하며, 선수동요의 경우에는 상대적으로 큰 1.3 도의 차이가 있음을 확인하였다. 선수동요의 차이가 큰 원인은 지자기 MEMS 센 서는 지구의 자기장을 측정하여 magnetic heading으로 방위 각을 계산하지만 지구의 자기장이 약하기 때문에 이를 측정 하여 방위로 환산할 경우 높은 오차를 보이므로 지자기 외란 에 대한 보상 또는 주기적으로 자이로를 통한 교정이 필요하 기 때문인 것으로 추정되므로(Rotenberg et al., 2005), AHRS 센서로 측정된 heading 계측 값이 실측 값인 자이로 컴파스 에 의한 값보다 변동 폭이 크게 나타났다. 그러므로 $\mathrm{AHRS}$ 센서를 이용한 heading 값에 대한 선수동요 계산의 정확도를 향상시키기 위해서는 향후 이에 대한 추가적인 연구가 필요 한 것으로 판단된다.

\section{4. 결 론}

본 논문에서는 MEMS AHRS 센서 기반의 IMU를 이용하 여 선체 운동 계측 데이터를 획득하여 실시간 선체 운동을 모니터링 할 수 있는 무선 선체 운동 계측 시스템의 구현과 이와 관련된 알고리즘을 개발하였다.

본 연구에서 구현한 AHRS 센서 기반의 선체 운동 모니터 링 시스템은 선체 운동의 주요 평가 요소인 횡동요, 종동요, 선수동요의 회전 운동 값을 측정함에 있어 실제 해상에서 파 랑의 영향을 직접 받는 실선에서 실험한 결과 $\mathrm{AHRS}$ 의 횡동 요와 종동요에 대한 선체 운동 계측은 선수동요보다 비교적 정확성과 신뢰성이 높은 것으로 나타났으며, 선수동요 계측 에 대해서는 향후 정확성을 높일 수 있는 방안 및 알고리즘 개발에 대한 연구가 필요한 것으로 판단된다. 그리고, 선체 운동 계측 시스템에 무선 시스템을 접목시켜 선박의 제한된 환경 요건을 해소하여 실무에 편리하게 적용시켰다. AHRS 는 향후 hull stress monitor, loading master, electronic inclinometer, VDR(Voyage Data Recorder) 등의 고도화될 선박 안정성 평가를 위한 시스템의 기초 장비로 적용되어 여 러 선박 안전시스템 분야에서도 활용될 수 있을 것으로 기대 된다.

\section{후 기}

본 연구는 2012년도 정부(교육과학기술부)의 재원으로 한 국연구재단의 기초연구사업 지원을 받아 수행되었습니다(과 제번호 2011-0025046).

\section{References}

[1] JK Electronics(2012), IMU AHRS 10DOF Dragon Manual http://www.jkelec.co.kr

[2] Jo, A., Kang, Y. S., Park, B. J., Yu, C. S., Gu, S. O., No, H. G. and Gi, C. D.(2012), "Quaternion-based AHRS Improved by Inertial Sensor Bias Compensation”, KSAS, pp. 2066-2070.

[3] Kim, C. S., Lee, Y. S., Kong, K. Y., Jeong, C. H., Kim, D. H. and Cho, I. S.(2005), "A Study on the Development of Multi-Purpose Measurement System for the Evaluation of Ship Dynamic Motion", Journal of Navigation and Port Research, Vol. 29, No. 10, pp. 847-852.

[4] Kwon, S. T., Song, J. W., Hong, J. S., Yu, G. R. and Sagong, B. C.(2005), "Design and Testing of integrated MEMS GPS/AHRS Navigation system”, KACC, pp. 509-514.

[5] Priyanka A., Zainab S., Aboelmagd N. and Naser E. S.(2010), MEMS-Based Integrated Navigation, Artech House, Norwood, MA.

[6] Rotenberg, D., Luinge, H., Baten, C. and Veltink, P. ( 2005), "Compensation of Magnetic Disturbances improves Inertial and Magnetic Sensing of Human Body Segment Orientation", IEEE Trans. Neural Syst. Rehabil. Eng., Vol. 13, pp. 395-405.

[7] Ruva Tech(2011), Attitude Reference System - RTa Datasheet rev0.2, http://www.ruva.kr

[8] Yoon, H. K., Lee, G. J. and Lee, D. K.(2008), "Development of the Motion Monitoring System of a Ship", Journal of Navigation and Port Research, Vol. 32, No. 1, pp. 15-22.

[9] Zhu, R., Sun, D., Zhou, Z. and Wang, D.(2007), “A Linear Fusion Algorithm for Attitude Determination Using Low Cost MEMS-Based Sensors", Measurement, Vol. 40, No. 3, pp. $322-328$.

원고접수일 : 2013년 11월 11일

심사완료일 : 2013년 12월 26일

원고채택일 : 2013년 12월 26일 